\title{
Ownership Structure and Performance in China's listed Logistics Companies
}

\author{
Wei Liu \\ Xiamen university of Tan Kah Kee college \\ liuwei568@xujc.com
}

\begin{abstract}
Keywords: ownership structure, firm performance, corporate governance, listed logistics companies
\end{abstract}

\begin{abstract}
The ownership structure is the basis of the development of companies, and performance measurement is critical for company to improve incomes. This study has empirically examined the relationship between the ownership structure and firm performance using a balanced panel of listed logistics companies from 2011 to 2015. We argue that, the largest shareholder's shareholding ratio, state-owned shares ratio, the sum of square of portions held by the first to the tenth shareholders, rate of return on common stockholders' equity, company scale, Tobin Q, total assets turnover and corporate performance do a significantly positive on China's listed logistics performance; the top5 shareholder's shareholding ratio, the top10 shareholder's shareholding ratio, tradable share ratio, debt to assets ratio, undistributed profits per share do a negative side on China's listed logistics performance. Our findings provide an important implication of ownership structure and performance for Chinese listed logistics companies
\end{abstract}

\section{Introduction}

The Logistics industry, which develops rapidly in China, is a basic and strategic support to the development of China's economy. According to the China Federation of Logistics\& Purchasing (CFLP), the only social organization of logistics industry in China, the total amount of social logistics is up to 167.4 trillion RMB in the first three quarters of 2016 with the growth rate $6.1 \%$ year by year.

There is extensive research on the relationship between ownership structure and corporate performance. The seminal work by Berle and Means (1932) shows that the control of capital is focused on the managers, but ownership is dispersed in minority shareholders.[1]

In recent years, several studies have begun to discuss the phenomenon that whether or not the ratio of tradable share, the proportion of state-owned shares and performance have a positive or negative correlation. For example, Harold and Belen (2001) find no statistically significant relation between ownership structure and firm performance[2], $\mathrm{Wu}$ (2002) report that firm performance is significant $\mathrm{U}$ style related with the concentration of ownership structure and internal shareholder[3]. Arunima and SVD (2011) conclude that there is a significant and positive relation between firm performance and promoters holding[4].

Our methodology is underpinned by Yang and Cao(2007). Their standpoint shows that there are different correlations between the shareholding proportion of the biggest shareholder, the top5 shareholder, the Top10 shareholder and the performance of list commercial banks.[5]

This paper is aimed to evaluate the relationship between ownership structure and corporate performance for the China's listed logistics companies, as the logistics company is an important component of logistics industry. In addition, the operating income of listed transportation, storage, and postal companies is 871,895 billion RMB in 2015 .

This paper examines the impact of different ownership structures on 57 company performance among China's listed logistics companies. Our work contains the stocks in Chinese stock markets except B-shares. and covers the period from January 2011 through December 2015. 
We use economic value added as dependent variable,rather than return on assets, and controlling for rate of return on common stockholders' equity, company scale, Tobin Q, debt to assets ratio, total assets turnover and undistributed profits per share, we find a positive effect of ownership concentration on shareholder value and profitability, but the effect levels off for high ownership shares.

The rest of the paper is organized as follows. Section 1 proposes the research hypothesis. Section 2 reviews the data description. In section 3, it describes the variables and defined. In Section 4, we present hypothesis test and result. Section 5 shows the main empirical findings. Section 6 provides a number of explanations for our findings. Finally, we reach a conclusion in section 7.

\section{Hypothesis}

According to the agency theory, shareholders have different attitudes toward spending resources on monitoring, Minority Shareholders take account of free riding from other shareholders. There are different optimal ownership structures among different industries, and various concentration has different effects on corporate governance, In addition different types of corporate governance are determined by different shareholding structures. Merging these perspectives results in a positive influence on firm performance:

Hypothesis 1: The ownership of China's listed logistics companies positively affects firm performance.

As often proposed by some economists, the more concentrated ownership, the greater the incomes. The existing literatures hold the standpoint that the ownership concentration leads to small shareholders' interests infringed by big shareholders. On the other hand, when the proportion of state-owned shares is over a certain degree, it will not only give rise to the decrease in regulatory effectiveness, but it also improves the enterprise management innovation,combining these perspectives:

Hypothesis 2: There is a curvilinear relationship between the ownership of China's listed logistics companies and the performance.

Hypothesis 2a: ownership concentration is measured by the proportion of the biggest shareholder.

Hypothesis $2 \mathrm{~b}$ : ownership concentration is measured by the proportion of the top 5 shareholder.

Hypothesis 2c: ownership concentration is measured by the proportion of the Top10 shareholder.

Hypothesis $2 \mathrm{~d}$ : There is a curvilinear relationship between the proportion of Shrhfd10 of China's listed logistics companies and the performance.

Hypothesis 2e: The state-owned shares ratio of China's listed logistics companies positively affects company performance.

Hypothesis 2f: The tradable share ratio of China's listed logistics companies positively affects company performance.

\section{Data Description}

The data for Chinese stocks is obtained from the Wind database and CSMAR. Stocks from both the Shanghai Stock Exchange and the Shenzhen Stock Exchange are included.

we select data based on the following 3 standards for selection:(1) Company data is only concerned with the A share market. (2) Not including the companies whose data is not full. (3) Not including the ST and *ST Inc. Finally got the 57 listed logistics Corporation. The companies are shown in Table 1. 
Table1 Selected Firms number table

\begin{tabular}{|c|c|c|c|c|c|}
\hline Num. & Company name & Num. & Company name & Num. & Company name \\
\hline 1 & Chiwan Wharf & 20 & $\begin{array}{l}\text { China Shipping } \\
\text { Development }\end{array}$ & 39 & Dazhong Transportation \\
\hline 2 & Yan Tian Port & 21 & China Southern Airlines & 40 & $\begin{array}{l}\text { Jin Jiang International } \\
\text { Industrial Investment }\end{array}$ \\
\hline 3 & Shenzhen Airport & 22 & China Eastern Airlines & 41 & Qiangsheng Holding \\
\hline 4 & Citic Offshore Helicopter & 23 & Shenzhen Expressway & 42 & Shanghai Jiao Yun \\
\hline 5 & $\begin{array}{l}\text { Guangdong Provincial } \\
\text { Expressway }\end{array}$ & 24 & $\begin{array}{l}\text { Hubei Chutian } \\
\text { Expressway }\end{array}$ & 43 & Shanghai Yatong \\
\hline 6 & Zhuhai Port & 25 & Yangtze River Investment & 44 & Tianjin Port \\
\hline 7 & Hunan Investment & 26 & Jinzhou Port & 45 & CMST Development \\
\hline 8 & Beibuwan Port & 27 & Hainan Airlines & 46 & $\begin{array}{l}\text { Zhangjiagang Freetrade } \\
\text { Science and Technology }\end{array}$ \\
\hline 9 & Xiandai Investment & 28 & $\begin{array}{l}\text { Jiangxi Ganyue } \\
\text { Expressway }\end{array}$ & 47 & Ningbo Marine \\
\hline 10 & Xiamen Port & 29 & $\begin{array}{l}\text { Sinotrans Air } \\
\text { Transportation }\end{array}$ & 48 & Tangshan Port \\
\hline 11 & Jiangsu Aucksun & 30 & Chongqing Gangjiu & 49 & China Shipping Haisheng \\
\hline 12 & Hainan Strait Shipping & 31 & Yingkou Port & 50 & Lianyungang Port \\
\hline 13 & Sichuan Fulin & 32 & Shandong Hi-Speed & 51 & Ningbo Port \\
\hline 14 & Zhuhai Winbase & 33 & Jiangsu Expressway & 52 & Sichuan Expressway \\
\hline 15 & Hubei Expressway & 34 & Wuzhou Communications & 53 & Air China \\
\hline 16 & $\begin{array}{l}\text { Shanghai International } \\
\text { Airport }\end{array}$ & 35 & COSCO Shipping & 54 & Jilin Expressway \\
\hline 17 & Anhui Expressway & 36 & $\begin{array}{l}\text { Chongqing Road \& } \\
\text { Bridge }\end{array}$ & 55 & $\begin{array}{l}\text { China Shipping Container } \\
\text { Lines }\end{array}$ \\
\hline 18 & Rizhao Port & 37 & Jiangxi Changyun & 56 & $\begin{array}{l}\text { China Merchants Energy } \\
\text { Shipping }\end{array}$ \\
\hline 19 & Shanghai International Port & 38 & Wanjiang Logistics & 57 & Dalian Port PDA \\
\hline
\end{tabular}

\section{Variables and Defined}

The variables used in this reseach are tabulated in Table 2 and defined as follows

Table 2 Variables definition

\begin{tabular}{|c|c|c|c|}
\hline Variable type & Variable name & Abbreviation & meaning \\
\hline $\begin{array}{l}\text { Dependent } \\
\text { Variable }\end{array}$ & Economic Value Added & eva & $\begin{array}{l}\text { eva }=(\text { after-tax operating } \\
\text { profit })-(\text { weighted average cost of } \\
\text { capital }) *(\text { cost of capital })\end{array}$ \\
\hline \multirow[t]{6}{*}{$\begin{array}{l}\text { Independent } \\
\text { Variable }\end{array}$} & $\begin{array}{l}\text { The largest shareholder's } \\
\text { shareholding } \\
\text { ratio }\end{array}$ & CR1 & $\begin{array}{l}\text { The number of the largest } \\
\text { shareholder's shares/total number } \\
\text { of shareholder's shares }\end{array}$ \\
\hline & $\begin{array}{l}\text { The top5 shareholder's } \\
\text { shareholding } \\
\text { ratio }\end{array}$ & CR5 & $\begin{array}{l}\text { The sum of the top } 5 \text { shareholder's } \\
\text { shares/total number of } \\
\text { shareholder's shares }\end{array}$ \\
\hline & $\begin{array}{l}\text { The top10 shareholder's } \\
\text { shareholding } \\
\text { ratio }\end{array}$ & CR10 & $\begin{array}{l}\text { The sum of the top } 10 \\
\text { shareholder's shares/total number } \\
\text { of shareholder's shares }\end{array}$ \\
\hline & state-owned shares ratio & ss & state-owned shares/total shares \\
\hline & tradable share ratio & ts & tradable shares/total shares \\
\hline & $\begin{array}{l}\text { The sum of square of } \\
\text { portions held by } \\
\text { the first to the tenth } \\
\text { shareholders }\end{array}$ & Shrhfd10 & Reflect the equity restriction \\
\hline control Variable & $\begin{array}{l}\text { Rate of Return on } \\
\text { Common Stockholders' } \\
\text { Equity }\end{array}$ & ROE & $\mathrm{ROE}=$ net profit/ owner's equity \\
\hline
\end{tabular}




\begin{tabular}{|l|l|l|l|}
\hline & company scale & size & $\begin{array}{l}\text { ln(The final total assets of } \\
\text { company) }\end{array}$ \\
\cline { 2 - 4 } & Tobin Q & tobin & Tobin Q to measure \\
\cline { 2 - 4 } & Debt to assets ratio & dar & dar= total debt/ total assets \\
\cline { 2 - 4 } & Total Assets Turnover & tat & tat=sales revenue/ total assets \\
\cline { 2 - 4 } & $\begin{array}{l}\text { Undistributed profits per } \\
\text { Share }\end{array}$ & upc & $\begin{array}{l}\text { Undistributed profits } \\
\text { /capitalization }\end{array}$ \\
\hline
\end{tabular}

\section{Hypothesis Test and Result}

The purpose of this study is to provide a comprehensive analysis how firm performance gets impacted by ownership structures.We use performance (eva) at the end of fiscal year as dependent variable and the largest shareholder's shareholding ratio(CR1), the top5 shareholder's shareholding ratio(CR5), the top10 shareholder's shareholding ratio(CR10), state-owned shares ratio(ss), tradable share ratio(ts), we employ the sum of square of portions held by the first to the tenth shareholders as independent Variable. We take Rate of Return on Common Stockholders' Equity, company scale. The Chinese listed logistics companies' 5-year overall descriptive statistics of each variable show in Table3. The table shows the number of variabels $(\mathrm{N})$, maximal value(max), minimal value(min), mean value(mean) and standard deviation(sd)

Table3 Descriptive statistics of each variable

\begin{tabular}{|c|c|c|c|c|c|}
\hline variable & $\mathrm{N}$ & $\max$ & $\min$ & mean & sd \\
\hline eva & 285 & $3.6 \times 10^{9}$ & $-5.7 \times 10^{9}$ & $-6.7 \times 10^{7}$ & $1.1 \times 10^{9}$ \\
\hline ROE & 285 & 32.38 & -58.27 & 7.92 & 7.316 \\
\hline Tobin & 285 & 5.189 & 0.77 & 1.47 & 0.64 \\
\hline size & 285 & 16.88 & 11.36 & 13.89 & 1.24 \\
\hline CR1 & 285 & 79.47 & 14.11 & 43.19 & 13.51 \\
\hline CR5 & 285 & 91.09 & 24.92 & 61.61 & 16.84 \\
\hline CR10 & 285 & 91.48 & 26.53 & 63.89 & 16.75 \\
\hline Shrhf10 & 285 & 0.632 & 0.03 & 0.231 & 0.122 \\
\hline ss & 285 & 0.83 & 0 & 0.10 & 0.19 \\
\hline ts & 285 & 1 & 0.15 & 0.88 & 0.20 \\
\hline dar & 285 & 0.83 & 0.01 & 0.46 & 0.18 \\
\hline tat & 285 & 2.34 & 0.03 & 0.42 & 0.38 \\
\hline upc & 285 & 7.53 & -0.73 & 1.36 & 1.28 \\
\hline
\end{tabular}

Table3 reports some results that: (1) Economic Value Added (eva) ranges from $-5.7 \times 10^{9}$ to $3.6 \times 10^{9}$, the deviation is high. (2) Rate of Return on Common Stockholders' Equity(ROE) (3) Tobin Q goes smoothly during 2011 and 2015 .

The means of state-owned shares ratio(ss) of Chinese listed logistics companies is close to 0.10 . Nevertheless, the tradable share ratio(ts) is up to 0.88 . The state-owned shares ratio is lower and lower. (3) the means of the largest shareholder's shareholding ratio(CR1) reaches 0.44 , It indicates that ownership structure of China's listed logistics companies is very concentrated. But the top5 shareholder's shareholding ratio(CR5) and the top10 shareholder's shareholding ratio (CR10) is similar. While the means of Debt to assets ratio(dar) and Total Assets Turnover(tat) are nearly 0.50, and the means of Undistributed profits per Share(upc) is 1.36.

Table4 Average changing tendency of eva (2011-2015)

\begin{tabular}{|c|c|c|c|c|c|}
\hline year & $\mathrm{N}$ & mean & $25 \%$ & $50 \%$ & $75 \%$ \\
\hline 2011 & 57 & $1.96 \times 10^{8}$ & $-4.85 \times 10^{6}$ & $1.09 \times 10^{8}$ & $4.06 \times 10^{8}$ \\
\hline 2012 & 57 & $-1.64 \times 10^{7}$ & $-5.12 \times 10^{7}$ & $2.29 \times 10^{7}$ & $2.85 \times 10^{8}$ \\
\hline 2013 & 57 & $-2.28 \times 10^{8}$ & $-6.17 \times 10^{7}$ & $1.29 \times 10^{7}$ & $1.66 \times 10^{8}$ \\
\hline 2014 & 57 & $-1.52 \times 10^{8}$ & $-1.72 \times 10^{8}$ & $-8.63 \times 10^{5}$ & $1.60 \times 10^{8}$ \\
\hline 2015 & 57 & $-1.38 \times 10^{8}$ & $-1.30 \times 10^{8}$ & $-8.17 \times 10^{6}$ & $1.31 \times 10^{8}$ \\
\hline
\end{tabular}


As shown in Table 4, the eva decreased from $1.96 \times 10^{8}$ in 2011 to $-2.28 \times 10^{8}$ in 2013 , and rose from $-1.52 \times 10^{8}$ in 2014 to $-1.38 \times 10^{8}$ in 2015 . The results of percentile are given in Table4. We can find that the eva is negative in 25th percentile from 2011 to 2015; At the same time, the eva is positive in 50th percentile during 2011 and 2013,but it is negative in 2014 and 2015, this is in line with the overall trend of market changes. The volume of international trade falls off in recent two year which influence the total asset yields of logisitics listed companies, but the eva is positive in 75 th percentile at last.

Table5 The changing trend of the CR1(2011-2015)

\begin{tabular}{|c|c|c|c|c|c|}
\hline year & $\mathrm{N}$ & mean & $25 \%$ & $50 \%$ & $75 \%$ \\
\hline 2011 & 57 & 43.19 & 32.51 & 42.22 & 51.17 \\
\hline 2012 & 57 & 43.81 & 34.46 & 42.27 & 51.01 \\
\hline 2013 & 57 & 43.73 & 32.52 & 41.9 & 51.33 \\
\hline 2014 & 57 & 43.31 & 33.67 & 41.09 & 51.33 \\
\hline 2015 & 57 & 41.92 & 32.52 & 40.37 & 50.91 \\
\hline
\end{tabular}

In Table5,it can be noticed that, from 2011 to 2012, the largest shareholding ratio(CR1) increased from $43.19 \%$ in 2011 to $43.81 \%$ in logistics listed companies in 2012 , to $43.73 \%$ and $41.92 \%$ respectively. The results of percentile are shown in Table5. It can seen that the largest shareholding ratio(CR1) is about 33\% in 25th percentile among 2011 and 2015;meanwhile, the largest shareholding ratio(CR1) decreas gradually in 50th percentile, but it is around 51\% in 75 th percentile, the change of the largest shareholding ratio(CR1) is not significant, the first major shareholders began to decentralize the share ownership structure.

Table6 The changing trend of the CR5(2011-2015)

\begin{tabular}{|c|c|c|c|c|c|}
\hline year & $\mathrm{N}$ & mean & $25 \%$ & $50 \%$ & $75 \%$ \\
\hline 2011 & 57 & 62.00 & 54.72 & 63.08 & 72.75 \\
\hline 2012 & 57 & 61.28 & 53.43 & 60.94 & 74.09 \\
\hline 2013 & 57 & 62.99 & 53.02 & 63.74 & 74.19 \\
\hline 2014 & 57 & 61.43 & 50.54 & 60.94 & 74.07 \\
\hline 2015 & 57 & 60.33 & 46.19 & 60.52 & 73.97 \\
\hline
\end{tabular}

As you can see from Table6, 2011 to 2015, in Chinese logistics listed companies the top 5\% largest shareholding ratio(CR5) rose from $62.00 \%$ in 2011 to $62.99 \%$ in 2013 . Subsequently, it fell to $60.33 \%$ in 2015 . The results of percentile are given in Table6, it shows that the top 5\% largest shareholding ratio(CR5) reduces from $54.72 \%$ to $46.19 \%$ in 25 th percentile, which fell gradually. The top 5\% largest shareholding ratio(CR5) reached 63.08\% in 50th percentile in 2011.However, it came down arriving at $60.94 \%$ in 2012; The top 5\% largest shareholding ratio(CR5) reached the peak value $63.74 \%$ in 2013 ,but fell to $60.52 \%$ in 50th percentile in 2015 . The top 5\% largest shareholding ratio(CR5) rose from $72.75 \%$ in 75 th percentile in 2011, which is the minimum during 2011 to 2015 ,to $74.19 \%$ in 2013.In the end, the top 5\% largest shareholding ratio(CR5) reduced to $73.97 \%$ in 2015.

Table7 The changing trend of the CR10(2011-2015)

\begin{tabular}{|c|c|c|c|c|c|}
\hline year & $\mathrm{N}$ & mean & $25 \%$ & $50 \%$ & $75 \%$ \\
\hline 2011 & 57 & 64.04 & 56.19 & 65.49 & 76.78 \\
\hline 2012 & 57 & 63.74 & 55.27 & 64.86 & 77.24 \\
\hline 2013 & 57 & 64.79 & 56.83 & 66.75 & 77.88 \\
\hline 2014 & 57 & 63.98 & 54.38 & 65.2 & 76.21 \\
\hline 2015 & 57 & 62.92 & 49.96 & 63.22 & 76.49 \\
\hline
\end{tabular}

As is seen in the Table7 given above, the top $10 \%$ largest shareholding ratio(CR10) decreased from $64.04 \%$ in 2011 to $63.74 \%$ in 2012 , and arrived at $62.92 \%$ in 2015 ultimately . The results of percentile are given in Table7. The top 10\% largest shareholding ratio(CR10) reached $56.19 \%$ in 25th percentile in 2011, but it reduced to $49.96 \%$ in 2015; The top $10 \%$ largest shareholding ratio(CR10) was about 65\% in 50th percentile in the period from 2011 to 2015 ; The top $10 \%$ largest shareholding ratio(CR10) reached 76.5\% in 75th percentile among 2011 and 2015. 
Table8 The changing trend of the Shrhfd10 (2011-2015)

\begin{tabular}{|c|c|c|c|c|c|}
\hline year & $\mathrm{N}$ & mean & $25 \%$ & $50 \%$ & $75 \%$ \\
\hline 2011 & 57 & 0.23 & 0.17 & 0.23 & 0.28 \\
\hline 2012 & 57 & 0.24 & 0.17 & 0.23 & 0.28 \\
\hline 2013 & 57 & 0.24 & 0.15 & 0.23 & 0.29 \\
\hline 2014 & 57 & 0.23 & 0.14 & 0.23 & 0.30 \\
\hline 2015 & 57 & 0.23 & 0.14 & 0.22 & 0.28 \\
\hline
\end{tabular}

As can be seen in Table8, 2011 to 2015, in listed companies in the logistics, the sum of square of portions held by the first to the tenth shareholders(Shrhfd10) kept the same percentage, which is within the range 0.23 to 0.24 . That, among 2011 to 2015 Chinese logistics listed companies' the sum of square of portions held by the first to the tenth shareholders(Shrhfd10) was stable. The results of percentile are given in Table8. The sum of square of portions held by the first to the tenth shareholders(Shrhfd10) fell from 0.17 to 0.14 in 25 th percentile,but the sum of square of portions held by the first to the tenth shareholders(Shrhfd10) reached 0.28 in 75 th percentile,that is to say, the equity was not restricted significantly.

Table9 shows Pearson's correlation of each variable in Chinese listed logistics companies from 2011 to 2015.

Table9 Pearson's correlation of the variables in 2011-2015

\begin{tabular}{|l|l|l|l|l|l|l|l|l|}
\hline & eva & ROE & ss & ts & CR1 & CR5 & CR10 & Shrhfd10 \\
\hline eva & 1 & & & & & & & \\
\hline ROE & $0.463^{* * * *}$ & 1 & & & & & & \\
\hline ss & 0.087 & 0.019 & 1 & & & & & \\
\hline ts & $0.121^{* * *}$ & -0.056 & $-0.921^{* * *}$ & 1 & & & & \\
\hline CR1 & $-0.118^{* *}$ & 0.036 & $0.337^{* * *}$ & $-0.282^{* * *}$ & 1 & & & \\
\hline CR5 & 0.085 & $0.123^{* *}$ & $0.168^{* * *}$ & $-0.155^{* * *}$ & $0.488^{* * *}$ & 1 & & \\
\hline CR10 & -0.057 & $0.150^{* *}$ & $0.164^{* * *}$ & $-0.174^{* * *}$ & $0.457^{* * *}$ & $0.975^{* * *}$ & 1 & \\
\hline Shrhfd10 & -0.046 & 0.067 & $0.333^{* * *}$ & $-0.269^{* * *}$ & $0.922^{* * *}$ & $0.668^{* * *}$ & $0.639^{* * *}$ & 1 \\
\hline
\end{tabular}

Standard errors in parentheses ${ }^{*} p<0.05,{ }^{* *} p<0.01,{ }^{* * *} p<0.001$

Table9 indicates the correlation coefficients between each variable. We can find that : (1)state-owned shares ratio(ss) have a negative correlation with the tradable share ratio(ts), and state-owned shares ratio(ss) has a positive effect on the largest shareholder's shareholding ratio(CR1), the top5 shareholder's shareholding ratio(CR5), the top10 shareholder's shareholding ratio( CR10) and the sum of square of portions held by the first to the tenth shareholders(Shrhfd10).(2) tradable share ratio(ts) have a negative correlation with the largest shareholder's shareholding ratio(CR1), the top5 shareholder's shareholding ratio(CR5), the top10 shareholder's shareholding ratio( CR10) and the sum of square of portions held by the first to the tenth shareholders(Shrhfd10).

This study uses Economic Value Added (eva) to measure the market-based performance. In Table 9, Economic Value Added (eva) is positively related with state-owned shares ratio(ss), and it is also positively related with state-owned shares ratio(ss). Consequently, We can accept the hypothesis1.In other word, China's listed logistics companies' ownership always positively affects firm performance.

In order to examine the other hypothesis above. We consider performance variable,which is Economic Value Added (eva), as dependent variable. Then it regressed on various independent variables and control variables. The Equations are given below:

Eq1: Performance $i t=\mathrm{a}+\mathrm{b} 1(\mathrm{CR} 1) i t+\mathrm{b} 2(\mathrm{CR} 1) i t^{2}+\gamma \mathrm{X} i t+\delta \mathrm{i}+\varepsilon i t$

Eq2: Performance $i t=\mathrm{a}+\mathrm{c} 1(\mathrm{CR} 5) i t+\mathrm{c} 2(\mathrm{CR} 5) i t^{2}+\gamma \mathrm{X} i t+\delta \mathrm{i}+\varepsilon i t$

Eq3: Performance $i t=\mathrm{a}+\mathrm{d} 1(\mathrm{CR} 10) i t+\mathrm{d} 2(\mathrm{CR} 10) i t^{2}+\gamma \mathrm{X} i t+\delta \mathrm{i}+\varepsilon i t$

Eq4: Performance it $=\mathrm{a}+\mathrm{e} 1(\operatorname{Shrhfd10}) i t+\mathrm{e} 1(\operatorname{Shrhfd10}) i t^{2}+\gamma \mathrm{X} i t+\delta \mathrm{i}+\varepsilon i t$ 
Eq5: Performance $i t=\mathrm{a}+\mathrm{f} 1(\mathrm{ss}) i t+\mathrm{f} 2(\mathrm{ss}) i t^{2}+\gamma \mathrm{X} i t+\delta \mathrm{i}+\varepsilon i t$

Eq6: Performance $i t=\mathrm{a}+\mathrm{g} 1(\mathrm{ts}) i t+\mathrm{g} 2(\mathrm{ts}) i t^{2}+\gamma \mathrm{X} i t+\delta \mathrm{i}+\varepsilon i t$

$\mathrm{X}$ it means ROE size Tobin dar tat and upc.

we apply Hausman test for statistically significant differences in the coefficients on the time-varying explanatory variables.In the end, a rejection using the Hausman test is taken to mean that the random effects assumption is false, and then the fixed effects estimates are used.

Table 10 Regression analysis of the Economic Value Added (eva)

\begin{tabular}{|c|c|c|c|c|c|c|}
\hline & $(1)$ & (2) & (3) & (4) & $(5)$ & $(6)$ \\
\hline & eva & eva & eva & eva & eva & eva \\
\hline \multirow[t]{2}{*}{ CR1 } & $6.2 \times 10^{7 * * *}$ & & & & & \\
\hline & $\left(2 \times 10^{7}\right)$ & & & & & \\
\hline \multirow[t]{2}{*}{ CR1_2 } & $-6 \times 10^{5 * * *}$ & & & & & \\
\hline & $\left(2 \times 10^{5}\right)$ & & & & & \\
\hline \multirow[t]{2}{*}{ CR5 } & & $-4.9 \times 10^{7}$ & & & & \\
\hline & & $\left(3.9 \times 10^{7}\right)$ & & & & \\
\hline \multirow[t]{2}{*}{ CR5_2 } & & $4.1 \times 10^{5}$ & & & & \\
\hline & & $\left(3.4 \times 10^{5}\right)$ & & & & \\
\hline \multirow[t]{2}{*}{ CR10 } & & & $-9.8 \times 10^{7 *}$ & & & \\
\hline & & & $\left(5.4 \times 10^{7}\right)$ & & & \\
\hline \multirow[t]{2}{*}{ CR10_2 } & & & $7.8 \times 10^{5 *}$ & & & \\
\hline & & & $\left(4.6 \times 10^{5}\right)$ & & & \\
\hline \multirow[t]{2}{*}{ Shrhfd10 } & & & & $2 \times 10^{9}$ & & \\
\hline & & & & $\left(1.7 \times 10^{9}\right)$ & & \\
\hline \multirow[t]{2}{*}{ Shrhfd10_2 } & & & & $-2.8 \times 10^{9}$ & & \\
\hline & & & & $\left(2.2 \times 10^{9}\right)$ & & \\
\hline \multirow[t]{2}{*}{ ss } & & & & & $1.2 \times 10^{8}$ & \\
\hline & & & & & $\left(2.4 \times 10^{8}\right)$ & \\
\hline \multirow[t]{2}{*}{ ts } & & & & & & $-8.3 \times 10^{7}$ \\
\hline & & & & & & $\left(2.2 \times 10^{8}\right)$ \\
\hline \multirow[t]{2}{*}{ ROE } & $6.7 \times 10^{7 * * *}$ & $6.5 \times 10^{7 * * *}$ & $6.6 \times 10^{7 * * *}$ & $6.5 \times 10^{7 * * *}$ & $6.5 \times 10^{7 * * *}$ & $6.5 \times 10^{7 * * *}$ \\
\hline & $\left(1.8 \times 10^{7}\right)$ & $\left(1.7 \times 10^{7}\right)$ & $\left(1.8 \times 10^{7}\right)$ & $\left(1.7 \times 10^{7}\right)$ & $\left(1.7 \times 10^{7}\right)$ & $\left(1.8 \times 10^{7}\right)$ \\
\hline \multirow[t]{2}{*}{ size } & $6.6 \times 10^{7}$ & $-2.4 \times 10^{7}$ & $-5.8 \times 10^{8}$ & $4.4 \times 10^{7}$ & $3.1 \times 10^{7}$ & $3.2 \times 10^{7}$ \\
\hline & $\left(1.2 \times 10^{8}\right)$ & $\left(1.6 \times 10^{8}\right)$ & $\left(1.7 \times 10^{8}\right)$ & $\left(1.5 \times 10^{8}\right)$ & $\left(1.4 \times 10^{8}\right)$ & $\left(1.4 \times 10^{8}\right)$ \\
\hline \multirow[t]{2}{*}{ Tobin } & $6.7 \times 10^{7}$ & $5.3 \times 10^{7}$ & $5.9 \times 10^{7}$ & $5.5 \times 10^{7}$ & $5.4 \times 10^{7}$ & $5.3 \times 10^{7}$ \\
\hline & $\left(5.0 \times 10^{7}\right)$ & $\left(5.2 \times 10^{7}\right)$ & $\left(5.8 \times 10^{7}\right)$ & $\left(5 \times 10^{7}\right)$ & $\left(5.3 \times 10^{7}\right)$ & $\left(5.4 \times 10^{7}\right)$ \\
\hline \multirow[t]{2}{*}{ dar } & $-1.4 \times 10^{9 * *}$ & $-1.2 \times 10^{9 *}$ & $-1.0 \times 10^{9 *}$ & $-1.4 \times 10^{9 * *}$ & $-1.2 \times 10^{9 *}$ & $-1.2 \times 10^{9 *}$ \\
\hline & $\left(6.4 \times 10^{8}\right)$ & $\left(6.3 \times 10^{8}\right)$ & $\left(5.9 \times 10^{8}\right)$ & $\left(6.7 \times 10^{8}\right)$ & $\left(6.3 \times 10^{8}\right)$ & $\left(6.4 \times 10^{8}\right)$ \\
\hline \multirow[t]{2}{*}{ tat } & $4.7 \times 10^{8 * *}$ & $4.5 \times 10^{8 *}$ & $4.6 \times 10^{8 *}$ & $4.5 \times 10^{8 *}$ & $4.3 \times 10^{8 *}$ & $4.3 \times 10^{8 *}$ \\
\hline & $\left(2.3 \times 10^{8}\right)$ & $\left(2.4 \times 10^{8}\right)$ & $\left(2.5 \times 10^{8}\right)$ & $\left(2.4 \times 10^{8}\right)$ & $\left(2.4 \times 10^{8}\right)$ & $\left(2.4 \times 10^{8}\right)$ \\
\hline \multirow[t]{2}{*}{ upc } & $-1.1 \times 10^{8}$ & $-1.2 \times 10^{8}$ & $-1.2 \times 10^{8}$ & $-1.1 \times 10^{8}$ & $-9.7 \times 10^{7}$ & $-9.9 \times 10^{7}$ \\
\hline & $\left(1.2 \times 10^{8}\right)$ & $\left(1.2 \times 10^{8}\right)$ & $\left(1.2 \times 10^{8}\right)$ & $\left(1.2 \times 10^{8}\right)$ & $\left(1.1 \times 10^{8}\right)$ & $\left(1.1 \times 10^{8}\right)$ \\
\hline
\end{tabular}




\begin{tabular}{|l|c|c|c|c|c|c|}
\hline $\mathrm{a}$ & $-2.5 \times 10^{9}$ & $1.5 \times 10^{9}$ & $3.4 \times 10^{9}$ & $-9.8 \times 10^{8}$ & $-5.8 \times 10^{8}$ & $-5.1 \times 10^{8}$ \\
\hline & $\left(1.7 \times 10^{9}\right)$ & $\left(2.7 \times 10^{9}\right)$ & $\left(3.1 \times 10^{9}\right)$ & $\left(1.9 \times 10^{9}\right)$ & $\left(1.7 \times 10^{9}\right)$ & $\left(1.8 \times 10^{9}\right)$ \\
\hline$N$ & 285 & 285 & 285 & 285 & 285 & 285 \\
\hline$R^{2}$ & 0.368 & 0.360 & 0.367 & 0.358 & 0.357 & 0.356 \\
\hline adj. $R^{2}$ & 0.349 & 0.341 & 0.349 & 0.339 & 0.340 & 0.340 \\
\hline
\end{tabular}

Standard errors in parentheses ${ }^{*} p<0.1,{ }^{* *} p<0.05,{ }^{* * *} p<0.01$

The results are summarized in Table10.Each column reports different regressions .Meanwhile,each row reports a coefficient estimate and standard error, p-value or other information, the standard error exceeds 0.368 , adjust standard error exceeds 0.349 .

Column(1) in Table 10 presents results for the panel data regression of the largest shareholder's shareholding ratio(CR1), Rate of Return on Common Stockholders' Equity(ROE), company scale (size), Tobin Q(tobin), Debt to assets ratio(dar), Total Assets Turnover(tat) and Undistributed profits per Share(upc). The coefficient of the largest shareholder's shareholding ratio(CR1) is positive $\left(6.2 \times 10^{7}\right)$ and the column (1) estimate is statistically significantly different from zero at the $1 \%$ level: Because of this estimation, increasing the largest shareholder's shareholding ratio(CR1) results in a higher Economic Value Added (eva). Therefore, the ownership concentration could be measured by the proportion of the biggest shareholder, supporting the hypothesis 2 a test.

However, the regression in column(2) suggest that the negative coefficient between Economic Value Added (eva) and the top5 shareholder's shareholding ratio(CR5) is $-4.9 \times 10^{7}$, and the column (2) estimate is not statistically significantly. Consequently, the ownership concentration could not be measured by the proportion of the top 5 shareholder, rejecting the hypothesis $2 \mathrm{~b}$ test.

The result in column(3) is not the same as in column(2), for the column (3) estimate is statistically significantly different from zero at the $10 \%$ level. Hence the ownership concentration could be measured by the proportion of the top10 shareholder, supporting the hypothesis $2 \mathrm{c}$ test.

According to the estimate in column(4), the coefficient on The sum of square of portions held by the first to the tenth shareholders(Shrhfd10) is positive $\left(2 \times 10^{9}\right)$ and the column (4) estimate is not statistically significantly different from zero at the $10 \%$ level, ownership concentration could be measured by Herfindahl10 index, passing the hypothesis 2 a test. At the same time, the proportion of Shrhfd10 is curvilinear relationship with firm performance, rejecting the hypothesis $2 \mathrm{~d}$ test

As reported in column (5) and column(6), the results in the two columns are not pass the T-tset. It shows that state-owned shares ratio(ss) and tradable share ratio(ts) are not statistically significantly, but state-owned shares ratio(ss) positive influence on Economic Value Added (eva), supporting the hypothesis 2e test. On the other hand,tradable share ratio(ts) negative influence on Economic Value Added (eva), rejecting the hypothesis $2 \mathrm{f}$ test.

\section{Conclusion and Further Discussion}

This study has empirically examined the relationship between the ownership structure and firm performance using a balanced panel of listed logistics firms from 2011 to 2015. Base on the results we obtained, the main conclusions of this article are as follows:

The model structure indicates that the largest shareholder's shareholding ratio(CR1) is a major contributon to the firm performance. There is a significant and positive relation between firm performance and the largest shareholder's shareholding ratio. Shares of holdings of the largest shareholder reflect the first shareholder thickness composing in reply stock right in enterprise of the ability making policy. Proprietary right is concentrating the all-important effect on a company's decision up. If height, proprietary right balance are insufficient very much,it slips up very easy to lead to policy; It makes a decision-making lose efficiency if proprietary right thickness is very low. The largest shareholder's shareholding ratio(CR1) holds the share proportion average has $43.19 \%$. Company scale is the corporate assets scale. Complying with the model result, it can be seen, 
logistics industry listed company assets scale has a obvious effect company's managing achievement. Assets scale is bigger, the higher total assets return rate bring back.

There are different degrees of factors affecting the performance.According to the results of the model, we can find that Total Assets Turnover (tat) is the most significant factors affecting Chinese listed companys' performance, and the second place factor is Rate of Return on Common Stockholders' Equity(ROE), the least significant factor is the Tobin Q(tobin). It shows strong profitability can contribute to higher performance.

The top 5 largest shareholder's shareholding ratio (CR5), the top 10 largest shareholder's shareholding ratio (CR10) and Undistributed profits per Share(upc) have negative correlations with company performance.The top 5 largest shareholder's shareholding ratio(CR5) and t top 10 largest shareholder's shareholding ratio (CR10) reflect the company's authority checks and balances. The higher authority checks and balances are, the bigger conflicts will exist among big shareholders.

Discussion

Lots of factors affect Chinese listed logistics company performance, and shareholder's shareholding ratio of the largest shareholder's shareholding ratio(CR1) in the ownership structure has positive influence. As a result, Chinese listed logistics companies get the first largest shareholder hold high shareholding ratio in a certain range so as to make sure to manage and supervise the company more effectively.

Company size has a positive correlation with corporate performance, so expanding the size of the logistics company in a certain range will acquire higher returns.

From the result of the regression, State-owned shares ratio(ss) is positive correlation with Economic Value Added (eva), meanwhile tradable share ratio(ts) is negative correlation with Economic Value Added (eva), Chinese listed logistics companies should concentrate on State-owned shares ratio(ss), in order to improve company performance.

\section{References}

[1] Berle A and Means G: The modern corporate and private property (McMillian, New York 1932).

[2] Demsetz H and Villalonga B:Journal of corporate finance. vol 7 (2001),p.209-233.

[3] Shu-kun W: China Industrial Economy. vol 166(2002),p.80-87.

[4] Haldar A, Rao S:Indian Journal of Corporate Governance. vol 4(2011),p. 27-34.

[5] FY Dong and LL Cheng: Chinese Journal of Management Science. vol 22(2014),p. 357-361.

[6] Yx Yang and Dy Cao: Journal of Financial Research. vol 323(2007),p. 87-97. 